\title{
Inadvertent reproduction of Eurocentrism in IR: The politics of critiquing Eurocentrism
}

\author{
Juliette Tolay* (D) \\ School of Public Affairs, Penn State Harrisburg, Middletown, Philadelphia, United States \\ *Corresponding author. Email: jtolay@psu.edu
}

(Received 6 July 2020; revised 19 March 2021; accepted 22 March 2021; first published online 30 April 2021)

\begin{abstract}
The study of 0Eurocentrism has become a hallmark of postcolonial International Relations theories. Of particular concern in this literature has been the resilience of Eurocentrism despite conscious efforts to move towards a post-Eurocentric understanding of world politics. This study argues that while existing works have highlighted many of the reasons why Eurocentrism persists today, it has not been sufficiently identified and conceptualised. In particular, why some policy actors, who have a vested interest in moving beyond Eurocentrism, inadvertently reproduce Eurocentrism? This article proposes to distinguish between different types of inadvertent reproductions. In particular it highlights rhetorical critique, deconstruction, decentring and dehierarchising, as different ways to critique, inadvertently reproduce and partially modify Eurocentrism. To illustrate this situation, this article looks at Turkey's migration policies and documents how Turkish governing elites have openly claimed the need to upend the Eurocentric order, yet have reproduced it in practice.
\end{abstract}

Keywords: Eurocentrism; Anti-Eurocentrism; Reproduction; Turkey; Migration; Foreign Policy

\section{Introduction}

The literature on Eurocentrism ${ }^{1}$ (in particular as it relates to international politics) has long highlighted the mechanisms through which it tends to reproduce itself. Despite several decades of studying and raising awareness of Eurocentrism, and despite a decrease in the relative power of Europe, and even the West, in the conduct of world politics, ${ }^{2}$ Eurocentrism can still be found striving in the ways many academics and practitioners conceptualise international politics. Many explanations provided to explain this puzzling reproduction have focused on how Eurocentrism is reproduced either intentionally or indifferently. ${ }^{3}$ In contrast, this article proposes

\footnotetext{
${ }^{1}$ For the purpose of this study, I privilege the term Eurocentrism over Western-centrism. It is mainly because of the history and genealogy of the term Eurocentrism, and the fact that the case analysed here deals mostly with European actors (and not with the broader Western/transatlantic community). I concur, however, with analyses that have highlighted the overlap and nuances between the two terms, the overall relevance of Western-centrism today given the recent history of US hegemony (and Europe as its partner), as well as the need to also distinguish between US-centrism and the European critique of US-centrism (hence the need to highlight differences within the West). As put by Fisher Onar and Nicolaïdis, 'Eurocentrism was thus embedded in a broader Western-centrism with two twists: not all Western-centrism is Eurocentric; and some forms of Eurocentrism patently challenge American-centrism.' Nora Fisher Onar and Kalypso Nicolaïdis, 'The decentring agenda: Europe as a post-colonial power', Cooperation and Conflict, 48:2 (2013), p. 284. See also Samir Amin, Eurocentrism (New York: Monthly Review Press, 1989), p. xiii.

${ }^{2}$ Deniz Kuru, 'Historicising Eurocentrism and anti-Eurocentrism in IR: A revisionist account of disciplinary selfreflexivity', Review of International Studies, 42 (2016), pp. 351-76.

${ }^{3}$ See, for instance, Kamran Matin, 'Redeeming the universal: Postcolonialism and the inner life of Eurocentrism', European Journal of International Relations, 19:2 (2011), pp. 353-77; Zeynep Gülşah Çapan, Re-Writing International Relations: History and Theory Beyond Eurocentrism in Turkey (London: Rowman \& Littlefield Publishers, 2016).

(C) The Author(s), 2021. Published by Cambridge University Press on behalf of the British International Studies Association. This is an Open Access article, distributed under the terms of the Creative Commons Attribution licence (http://creativecommons.org/licenses/by/4.0/), which permits unrestricted re-use, distribution, and reproduction in any medium, provided the original work is properly cited.
} 
to analyse the inadvertent reproduction of Eurocentrism, which has received less attention. Accordingly, this article addresses the question of why actors, who are aware of Eurocentrism and have an interest in overcoming it, often end up inadvertently reproducing Eurocentrism. This study is particularly interested in the critique and reproduction of Eurocentrism by practitioners of world politics. While most of the critique of Eurocentrism has been conducted by academicians, and major strides have 'yet to find significant uptake among policymakers and publics', ${ }^{4}$ I argue here that practitioners of world politics do engage in the critique of Eurocentrism, yet often end up reproducing it. This inadvertent reproduction has been documented, ${ }^{5}$ but it has not been conceptualised. This article proposes such a conceptualisation of inadvertent reproduction, in order to better situate inadvertent reproduction among other forms of reproductions and within the politics of Eurocentrism and anti-Eurocentrism. Its main contribution is to highlight that reproducing and overcoming Eurocentrism can best be understood not as two dichotomous practices, but rather as a continuum where many practices engage both in partial reproduction and partial overcoming of Eurocentrism. More specifically, it allows to unpack the different dimensions of the critique of Eurocentrism and to better assess the extent to which the inadvertent reproduction can also operate as a form of modified reproduction of Eurocentrism.

To illustrate this conceptual framework, I analyse the case of Turkey and its use of migration policies in the international context. Turkey, given its historical, geographical, and discursive positionality, has long presented an interesting case for the practice of postcolonial critique. But it has also often been a disappointed promise. Different aspects of Turkey's migration policy over the last twenty years can help illustrate several dimensions of inadvertent reproduction of Eurocentrism: namely rhetorical critique, decentring with a new centre, and inverted hierarchy. Furthermore, the Turkish illustration provide interesting insights into the value of modified reproduction and whether it represents an advancement towards an emancipated post-Eurocentric future, or a setback that solidifies the reality and strength of Eurocentrism.

\section{Definitions: Conceptualising epistemic and geopolitical Eurocentrisms}

Eurocentrism is now an established term within critical theory, even though its meaning and uses differ from author to author, and from field to field. Building on the early work of Samin Amin, Eurocentrism is often defined as a systematic distortion of knowledge, which tends to depict Europe (or the West) as superior. ${ }^{6}$ A lot of the scholarship has focused on the mainstream writing of world history that tends to be teleological and sees Europe as the self-producing initiator and leader, taking humanity through the steps of 'progress'. ${ }^{7}$ Such a writing tends to undervalue or ignore the other, the non-European, and the roles they played through history: 'Eurocentrism is tantamount to a refusal to recognize or acknowledge the otherness of the non-European Other.' ${ }^{8}$ Zeynep Gülşah Çapan focuses more on the spatial and temporal underpinnings of a Eurocentric system of knowledge, where 'Europe is written in as the originator of all developments (democracy, sovereignty, human rights) and ... that narrative structures the temporal and spatial hierarchies through which we understand the development of the international.'

\footnotetext{
${ }^{4}$ Fisher Onar and Nicolaïdis, 'The decentring agenda', p. 288.

${ }^{5}$ See, for instance, Zeynep Gülşah Çapan, 'Enacting the international/reproducing Eurocentrism', Contexto Internacional, 39:3 (2017), pp. 655-71.

${ }^{6}$ Amin, Eurocentrism, p. 74.

${ }^{7}$ Tarak Barkawi and Mark Laffey, 'The postcolonial moment in security studies', Review of International Studies, 32 (2006), pp. 329-52.

${ }^{8}$ Hwa Yol Jung, 'Postmodernity, Eurocentrism, and the future of political philosophy', in F. Dallmayr (ed.), Border Crossings: Toward a Comparative Political Theory (Lanham, MD: Lexington Books, 1999), p. 279.

${ }^{9}$ Zeynep Gülşah Çapan, 'Eurocentrism and the construction of the "Non-West"', E-International Relations (19 June 2018), available at: \{https://www.e-ir.info/2018/06/19/Eurocentrism-and-the-construction-of-the-non-west/\} accessed 24 January 2021.
} 
Accordingly, Europe is thought of as a space that is separate from the non-West (spatial hierarchy) and it is thought of as temporarily ahead the progressive narrative of the international. This temporal hierarchy has been covered by scholars such as Edward Said and Dipesh Chakrabarty under the term of 'historicism'. ${ }^{10}$ Within a Eurocentric worldview, Europe is always visualised as being ahead, at the centre, and at the top all at once.

Various typologies of Eurocentrism have highlighted the multifaceted nature of Eurocentrism. These typologies highlight the fact that expressions of Eurocentrism can take different forms, play different functions and act at different levels in the theory-practice continuum of world politics. Antoon de Baets, for instance, talks about five levels of Eurocentrism based on the assumptions made regarding the non-Western: ontological Eurocentrism ('Non-Western history does not exist'); epistemological Eurocentrism ('Non-Western history cannot be known'); ethical Eurocentrism ('Non-Western history has little value'); utilitarian Eurocentrism ('Non-Western history is not relevant or useful'); and didactic Eurocentrism ('Non-Western history is too difficult and too embarrassing'). ${ }^{11}$ Deniz Kuru distinguished between historical-contextual, ideological, and residual forms of Eurocentrism. He sees historical-contextual Eurocentrism as a 'natural' development accompanying the 'rise to global dominance of Europe's great powers in the nineteenth century'. Ideological Eurocentrism developed with, and then without, European dominance: it continues to construct and justify the centrality of Europe, even after Europe ceases to be the dominant force in IR. Finally, residual Eurocentrism is 'about scholars who have failed, for various reasons, to recognize the need to update their individual perspectives.... It concerns scholars employing Eurocentric perspectives without being aware of the problems generated by their choice. ${ }^{, 2}$ John Hobson has proposed another typology and discussed the differences between manifest and subliminal Eurocentrism. Manifest Eurocentrism, in turn, can be imperialist or not, and racist or not. Subliminal Eurocentrism can be orthodox or critical in nature. ${ }^{13}$ Here both Kuru and Hobson provide some clues as to why and how Eurocentrism is being reproduced over time.

One other way to distinguish between different types of Eurocentrism that is of particular interest for this study is to distinguish between epistemic Eurocentrism and geopolitical Eurocentrism. Accordingly, following terms used by Sinem Adar and Halil Ibrahim Yenigün, ${ }^{14}$ anti-Eurocentrism could be defined alternatively as a struggle against 'Western epistemologies' (epistemic Eurocentrism) or against 'Western hegemony' (geopolitical Eurocentrism). In the literature on Eurocentrism, most of the focus has been on the epistemic nature of Eurocentrism and the impact it has on how knowledge is generated. Eurocentrism is first and foremost a 'system of knowledge. ${ }^{15}$ In that sense, the study of Eurocentrism parallels the study of Orientalism as developed originally by Edward Said that systematically highlighted the self-perpetuating bias in narratives (and constitutive construction) about 'the other' found both in Academia and other more ubiquitous forms of representations (through the media, arts, literature, etc.). ${ }^{16}$ Beyond a common focus on the politics of representation, both highlight the self-conception of Europe as being distinctive and superior in relation to others, non-Europeans or non-Western. In the case of Orientalism though, the difference between the West and the Orient is ontological and

\footnotetext{
${ }^{10}$ Dipesh Chakrabarty, Provincializing Europe: Postcolonial Thought and Historical Difference (Princeton, NJ: Princeton University Press, 2000), p. 11; Edward Said, 'Orientalism reconsidered', Cultural Critique, 1 (1985), pp. 89-107.

${ }^{11}$ Antoon De Baets, 'Eurocentrism (Western colonialism)', What-When-How (n.d.), available at: \{http://what-when-how. com/western-colonialism/Eurocentrism-western-colonialism/\} accessed on 24 January 2021.

${ }^{12}$ Kuru, 'Historicising Eurocentrism', pp. 356-7.

${ }^{13}$ John M. Hobson, The Eurocentric Conception of World Politics: Western International Theory, 1760-2010 (New York: Cambridge University Press, 2012).

${ }^{14}$ Sinem Adar and Halil Ibrahim Yenigün, 'A Muslim counter-hegemony?: Turkey's soft power strategies and Islamophobia', Jaddaliyya (6 May 2019), available at: \{https://www.jadaliyya.com/Details/38646/A-Muslim-CounterHegemony-Turkey\%E2\%80\%99s-Soft-Power-Strategies-and-Islamophobia\} accessed 24 January 2021.

${ }^{15} \mathrm{Gül}$ șah Çapan, 'Construction of the non-West'.

${ }^{16}$ Edward Said, Orientalism (New York: Pantheon Books, 1978).
} 
assumed permanent, while in the case of Eurocentrism, the non-Europeans are expected to eventually follow the European lead and become European-like. ${ }^{17}$ In this respect, Orientalism and Eurocentrism work together as two alternative but overlapping systems of knowledge that support the power of Europe.

Beyond epistemic implications of the Eurocentric distortion, there are indeed important political implications to Eurocentrism. Eurocentrism has played - and continues to play - an essential role in legitimising the dominance of the West. Eurocentrism is a form of Foucauldian power/knowledge nexus that has been particularly dominant in the practice of International Relations over the last couple of centuries. ${ }^{18}$ In that sense, Eurocentrism is distinct from other forms of ethnocentrism or parochialism due to its intimate association with a successful and hegemonic global power project. However, this geopolitical Eurocentrism is also more difficult to conceptualise. At one level, geopolitical Eurocentrism is predicated on the political impact of a world where Europe or the West is perceived as superior both in material and moral terms. Does this mean that any practical attempt at challenging European supremacy is anti-Eurocentric? Is any anti-West, counter-hegemonic, antiimperialist move considered as anti-Eurocentric? Is any power move from a non-Western rising power in the Western dominated international system a form of anti-Eurocentrism? It seems that not all power projects are anti-Eurocentric per se. To be anti-Eurocentric (in the geopolitical sense of the term), there is a need to contest and challenge a specific form of discourse or representation that construct Europe as superior to other actors. However, in practice, such construction of superiority is not always explicit. One way to identify such implicit Eurocentrism is to highlight the arbitrary primacy of European interests in the definition of policies. But such a practical conception of Eurocentrism blurs again the line between anti-Eurocentrism and an anti-European power approach. This challenge is actually one of the reasons why Eurocentrism ends up being reproduced. Nevertheless, epistemic and geopolitical Eurocentrism address different problems (the former addresses an intellectual and ethical problem, while the latter addresses a practical and political problem), and, as will be shown below, might lead different actors to engage in different types of anti-Eurocentric projects.

The distinction between epistemic and geopolitical Eurocentrism should also not hide the extent to which both operate together and are mutually reinforcing. ${ }^{19}$ Epistemic Eurocentrism emerged at a time of considerable power of European actors, which has generated a push for the production of knowledge and scholarship that reflected and justified this power. In turn, the Eurocentric knowledge generated is used by practitioners as a means to legitimise and expand further the adoption of Eurocentric worldviews. Accordingly, questions of moral evaluation and ethics (regarding who or what is superior, better or legitimate) mediate in the process of mutual constitution of geopolitical and epistemic Eurocentrisms. Consequently, Eurocentrism as a praxis has also generated its antithesis as anti-Eurocentrism is not simply a scholarly critique of epistemic and geopolitical Eurocentrism, but anti-Eurocentrism itself has become used as a political praxis, in order to legitimise the criticism and undoing of a Europe-centred world order. ${ }^{20}$

\section{Criticising and reproducing Eurocentrism: Resilience through interests and a lack of awareness}

Eurocentrism is a term coined by its detractors. Actors talking about Eurocentrism tend to criticise it, and attempt to undermine it. There have been several decades now of uncovering the

\footnotetext{
${ }^{17}$ The author would like to thank the anonymous reviewer who helped sharpen this conceptualisation.

${ }^{18}$ Hobson, The Eurocentric Conception.

${ }^{19}$ Adar and Yenigün, 'A Muslim counter-hegemony?'.

${ }^{20}$ See, for instance, Bobby S. Sayyid, A Fundamental Fear: Eurocentrism and the Emergence of Islamism (London: Zed Books, 2003); Cemil Aydin, 'Between Occidentalism and the Global Left: Islamist critiques of the West in Turkey', Comparative Studies of South Asia, Africa and the Middle East, 26:3 (2006), pp. 446-61.
} 
negative impact that Eurocentrism has had on the world. Beyond normative requirements, material changes should also accelerate the demise of Eurocentrism: Kuru affirmed that Eurocentrism should recede in parallel to Europe's decline; ${ }^{21}$ Nora Fisher Onar and Kalypso Nicolaïdis also stated that the decentring agenda (to transcend Eurocentrism) is now 'a matter of pragmatism beyond being the "right' thing to do"'. ${ }^{22}$ How then, can we explain the survival and reproduction of Eurocentrism? Traditionally, reproduction is explained through the vested interest of powerful actors in the continuation of Eurocentrism, and the difficulties of the critique of Eurocentrism of raising awareness and providing an alternative to Eurocentrism. ${ }^{23}$

Most authors working on Eurocentrism have highlighted and discussed aspects of the continuation and reproduction of Eurocentrism. At the core of the argument lies the fact that the powerful (the West) benefits from a Eurocentric system of thought. Eurocentrism represents a vested interest for some. In Amin's words: 'Resistance to the critique of Eurocentrism is always extreme, for we are here entering the realm of the taboo .... For the critique of Eurocentrism directly calls into question the position of the comfortable classes of this world. ${ }^{24}$ Even in the face of ethical criticism, Western actors have a vested interest to - at most - actively perpetuate a Eurocentric worldview, or - at least - turning a blind eye to its existence. There is something comfortable in the passive acceptance of a worldview that validates you. This understanding was captured under the 'ideological Eurocentrism' of Kuru mentioned above. Such an explanation is particularly powerful to understand the resilience and reproduction of geopolitical Eurocentrism.

Another line of thought has highlighted the difficulties of understanding and recognising Eurocentric tendencies. Eurocentrism can be so pervasive and hegemonic that it is mostly invisible to all but trained eyes. Critiques of Eurocentrism often 'engage in a conversation that remains opaque to the uninitiated'. ${ }^{25}$ A lot of that remaining Eurocentrism might fall under the 'residual Eurocentrism' of Kuru. This explanation of the reproduction can enlighten our understanding of the resilience of geopolitical Eurocentrism by practitioners but it has also been articulated to explain the reproduction of epistemic Eurocentrism. Hobson talks of 'subliminal Eurocentris' to highlight how it can be expressed insidiously, even within the works of critical scholars. ${ }^{26}$ Indeed, even authors who attempt to write from an anti-Eurocentric perspective sometimes adopt Eurocentric common places in their thought and writings. Early on, Immanuel Wallerstein has warned us of the existence of 'anti-Eurocentric Eurocentrism'. ${ }^{27}$ Kuru also nicely summarised the many works of anti-Eurocentric scholars who have been themselves accused of being Eurocentric. ${ }^{28}$ Part of the problem goes even further and lies in the paradox that underpins many poststructuralist works: 'Poststructuralist texts inevitably reproduce and empower the discourse that they aim to deconstruct. ${ }^{, 29}$ Considerable academic efforts have been put in trying to build an alternative world to the Eurocentric one ${ }^{30}$ however there is a continuous (and important

\footnotetext{
${ }^{21}$ Kuru, 'Historicising Eurocentrism'.

${ }^{22}$ Fisher Onar and Nicolaïdis, 'The decentring agenda', p. 285.

${ }^{23}$ Matin, 'Redeeming the universal'.

${ }^{24}$ Amin, Eurocentrism, p. 116.

${ }^{25}$ Fisher Onar and Nicolaïdis, 'The decentring agenda', p. 288; see also Meera Sabaratnam, 'Avatars of Eurocentrism in the critique of the liberal peace', Security Dialogues, 44:3 (2013), pp. 259-78.

${ }^{26}$ Hobson, The Eurocentric Conception, p. 183.

${ }^{27}$ Immanuel Wallerstein, 'Eurocentrism and its avatars: The dilemmas of social science', Sociological Bulletin, 46:1 (1997), pp. 21-39.

${ }^{28}$ Kuru, 'Historicising Eurocentrism', p. 353.

${ }^{29}$ Münevver Cebeci, 'Deconstructing the EU's “standards of civilisation”: The case of Turkey', Uluslararasi Iliskiler, 16:64 (2019), pp. 77-91.

${ }^{30}$ One can cite here as examples of works on 'hybridity': Homi K. Bhabha, The Location of Culture (London: Routledge, 2004); Avtar Brah and Annie E. Coombes (eds), Hybridity and its Discontents: Politics, Science, Culture (London: Routledge, 2000); on pluralising agency: Anjali Prabhu, 'Interrogating hybridity: Subaltern agency and totality in postcolonial theory', Diacritics, 35:2 (2005), pp. 76-92; Vivienne Jabri, 'Disarming norms: Postcolonial agency and the constitution of the international', International Theory, 6:2 (2014), pp. 372-90; on uneven and combined development: Matin, 'Redeeming the
} 
and healthy) discussion regarding the extent to which these efforts are ultimately successful at building a real alternative. ${ }^{31}$

Further confounding has been the fact that the reproduction of Eurocentrism is not only done at the Western core or by Westerners, but also by actors situated at the imagined periphery. Elites in peripherical countries, as a means to cope with subjective hierarchies, have often indeed adopted the basic assumption of Eurocentric hierarchies to then argue that they are well situated within said hierarchy (or at least better situated than others). Zarakol has highlighted how countries such as Russia, Japan, and Turkey have used differing techniques to overcome the stigma of defeat, and a common one was to make the case that their country were 'Western', or 'modern' or 'civilized', and should gain international recognition as such. ${ }^{32}$ Students of postsocialist polities have coined the term 'secondary Eurocentrism' to refer to this reproduction by non-Europeans. ${ }^{33}$ By doing so, they were adopting and reproducing a Eurocentric frame of reference. Arguably, because the adoption of Eurocentric frames of references by non-Western actors functions as a form of external validation, such acts can perform an even stronger constitutive and reproductive role in Eurocentrism (compared to similar acts performed by Western/ European actors). This form of reproduction is operated both at the epistemic level (by non-European scholars) and at the geopolitical level (by non-Europeans political actors).

Accordingly, Eurocentrism is not just something that is, but rather something that is easier to adopt than to get rid of. To capture this reality, scholars have talked of Eurocentric enframing ${ }^{34}$ or Eurocentric entrapment. ${ }^{35}$ While providing important insights to understand the reproduction of Eurocentrism, these explanations do not really address the puzzle of why actors who are aware of Eurocentrism, do not benefit from Eurocentrism and actually have a lot to gain in undermining Eurocentrism, continue nevertheless to reproduce Eurocentrism (inadvertent reproduction).

\section{Conceptualising the inadvertent reproduction of Eurocentrism}

This article proposes to conceptualise the inadvertent reproduction of Eurocentrism. More specifically, it challenges the assumption that pins Eurocentrism against anti-Eurocentrism, and proposes to understand the politics of the critique of Eurocentrism as a continuum going from reproduction to overcoming, where most reactive practices to resist and critique Eurocentrism find themselves functionally as much reproducing as they are really overcoming Eurocentrism. As illustrated in Figure 1, there is some overlap between inadvertently reproducing Eurocentrism and overcoming Eurocentrism, often through the form of a 'modified reproduction'. This continuum, however, is multilayered and there are different ways to resist/critique Eurocentrism.

Table 1 summarises this conceptualisation of the different types of critiques of Eurocentrism and where they are situated on the reproduction/overcoming continuum. First, there is the

universal'; Kamran Matin, 'Uneven and Combined Development in World History: The International Relations of State-formation in Premodern Iran'; on connected histories and sociologies: Gurminder Bhambra, 'Historical sociologies, international relations and connected histories', Cambridge Review of International Affairs, 23:1 (2010), pp. 127-43; Gurminder Bhambra, 'Postcolonial and decolonial dialogues', Postcolonial Studies, 17:2 (2014), pp. 115-21; on global IR: Amitav Acharya, 'Global international relations (IR) and regional worlds: A new agenda for international studies', International Studies Quarterly, 58 (2014), pp. 647-59; Amitav Acharya, 'Advancing global IR: Challenges, contentions, and contributions', International Studies Review, 18 (2016), pp. 4-15, etc.

${ }^{31}$ For a recent example, see Felix Anderl and Antonia Witt, 'Problematising the global in global IR', Millennium online (4 December 2020), pp. 1-26.

${ }^{32}$ Ayşe Zarakol, After Defeat: How the East Learned to Love with the West (Cambridge: Cambridge University Press, 2011).

${ }^{33}$ See, for instance, Madina Tlostanova, 'Postsocialist $\neq$ postcolonial? On post-Soviet imaginary and global coloniality', Journal of Postcolonial Writing, 48:2 (2012), pp. 130-42.

${ }^{34}$ Jung, 'Postmodernity, Eurocentrism', p. 288.

${ }^{35}$ Melody Fonseca, 'Global IR and Western dominance: Moving forward or Eurocentric entrapment?', Millennium, 48:1 (2019), pp. 45-59. 


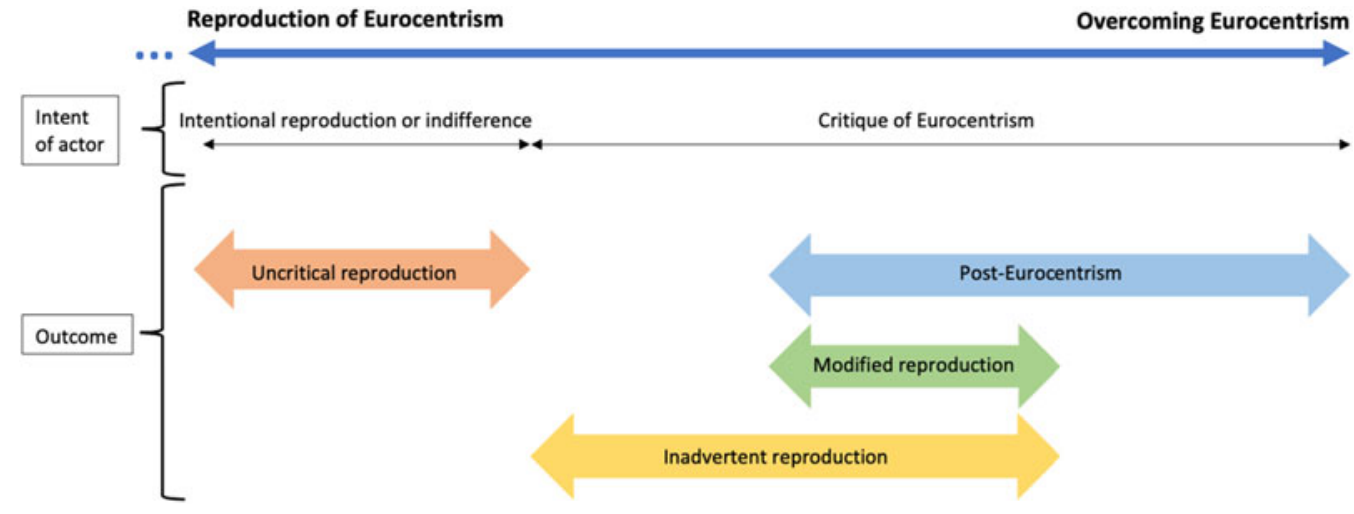

Figure 1. The Continum between reproduction and overcoming of Eurocentrism.

practice of a 'rhetorical critique' that tends to be mostly discursive and superficial, often used by practitioners. The second is an intellectual project of deconstruction that aims at raising awareness regarding the existence of Eurocentrism: this is an important project for post-structuralist scholars, but one that does not address the need of practitioners of world politics. Third, there is a decentring strategy, where Europe is taken away from the centre of history and world politics. Finally, the fourth strategy is one of dehierarchising, where Europe is no longer seen at the top of a constructed normative hierarchy.

The first two strategies (rhetorical critique and deconstruction) are mostly focused on the critique aspect: their main goal is to reveal and challenge the existing Eurocentric biases. When such a strategy is practiced by critical scholars, the goal of criticising Eurocentrism is not so much to provide an alternative to Eurocentrism: such an alternative might be elusive or inexistent, or beyond the point. The real emancipatory goal of critical scholarship is to highlight the existing inequalities and injustices embedded in the system. This critical awareness is a neverending process, because awareness will lead to a transformation of the system into a new system that, in turn, is likely to create its own hidden inequalities and injustices, requiring, in turn, the need for further critical scholarship. It is mainly a work of deconstruction as defined by the critical scholarship of Jacques Derrida. Such a work of deconstruction can both address geopolitical and epistemic Eurocentrism. As put by Sanjay Seth, the most important argument of postcolonial critique of Eurocentrism is that social sciences is 'fully adequate nowhere', ${ }^{36}$ which highlights the depth of the critique, as well as the a priori absence of a pristine solution or alternative. But as a result, this approach is typically insufficient or frustrating for practitioners who need clearer and more concrete guidance regarding what a post-Eurocentric world would look like, and what kind of political acts or policies can be put in place to achieve it. At the same time, practitioners might not be as trained and fluent in the poststructuralist language in which the scholarly critique of Eurocentrism tend to take place. As a result, there is a tendency for practitioners to engage in a critique of Eurocentrism that is more so focused on rhetoric and posturing (rather than specific political actions) and which can more easily blur the line between anti-Eurocentrism and anti-Europe (or anti-West) as discussed above. Such a rhetorical critique can often appear be superficial and insufficient to fully understand the mechanisms of Eurocentrism, and may more easily lead to inadvertent reproduction of Eurocentrism. Deconstruction is in principle more powerful in its ability to challenge eurocentrism, but given its lack of practical insights, it may also not be sufficient to fully overcome eurocentrism.

\footnotetext{
${ }^{36}$ Sanjay Seth, 'Historical sociology and postcolonial theory: Two strategies for challenging Eurocentrism', International Political Sociology, 3:3 (2009), pp. 334-8 (p. 337).
} 
Table 1. The different types of critique of Eurocentrism.

\begin{tabular}{|c|c|c|c|c|c|c|}
\hline $\begin{array}{l}\text { Types of critique } \\
\text { of Eurocentrism }\end{array}$ & Main logic & Subtype & $\begin{array}{l}\text { Target (Geopolitical or } \\
\text { Epistemic Eurocentrism) }\end{array}$ & Main actor & Likely outcome & $\begin{array}{l}\text { Illustration (case of } \\
\text { Turkish migration } \\
\text { policies) }\end{array}$ \\
\hline Rhetorical critique & $\begin{array}{l}\text { Superficial critique based on } \\
\text { discourse and geared at } \\
\text { immediate political gains }\end{array}$ & $\mathrm{N} / \mathrm{A}$ & (Mostly) geopolitical & (Mostly) practitioners & Inadvertent reproduction & $\begin{array}{l}\text { Continued externalisation } \\
\quad \text { (illustration 2) }\end{array}$ \\
\hline Deconstruction & $\begin{array}{l}\text { Raising awareness and } \\
\text { highlighting instances and } \\
\text { consequences of } \\
\text { Eurocentrism }\end{array}$ & $\mathrm{N} / \mathrm{A}$ & $\begin{array}{l}\text { Geopolitical and } \\
\text { epistemic }\end{array}$ & (Mostly) scholars & Indeterminate & \\
\hline \multirow[t]{3}{*}{ De-centring } & \multirow{3}{*}{$\begin{array}{c}\text { Challenging the assumption } \\
\text { that Europe/the West is at the } \\
\text { centre }\end{array}$} & New centre & (mostly) Geopolitical & Practitioners and scholars & Modified reproduction & \multirow[t]{3}{*}{$\begin{array}{l}\text { Critical Europeanisation } \\
\quad \text { (illustration 1) }\end{array}$} \\
\hline & & Multiple centre & $\begin{array}{l}\text { Geopolitical and } \\
\text { epistemic }\end{array}$ & Practitioners and scholars & $\begin{array}{l}\text { Inadvertent } \\
\text { reproduction/ } \\
\text { post-Eurocentrism }\end{array}$ & \\
\hline & & No centre & Epistemic & Scholars & Post Eurocentrism? & \\
\hline \multirow[t]{3}{*}{ De-hierarchising } & \multirow{3}{*}{$\begin{array}{l}\text { Challenging the norms and } \\
\text { hierarchy of norms that have } \\
\text { been determined by } \\
\text { Eurocentrism }\end{array}$} & Inverted hierarchy & $\begin{array}{l}\text { Geopolitical and } \\
\text { epistemic }\end{array}$ & Practitioners and scholars & Modified reproduction & \multirow[t]{3}{*}{$\begin{array}{l}\text { Humanitarian discourse } \\
\quad \text { (illustration 3) }\end{array}$} \\
\hline & & New hierarchy & $\begin{array}{l}\text { Geopolitical and } \\
\text { epistemic }\end{array}$ & Practitioners and scholars & Modified reproduction & \\
\hline & & No hierarchy & Epistemic & Scholar (postmodern) & Post-Eurocentrism? & \\
\hline
\end{tabular}


Beyond the practitioners' rhetorical critique, and the scholars' occasional satisfaction with deconstruction, there are two other strategies used to overcome Eurocentrism, which can bridge the gap between scholars and practitioners. The first one is decentring. There is now a flourishing literature on the project of decentring Europe or decentring International Relations, which have mostly focused on epistemic Eurocentrism, ${ }^{37}$ but have also developed some insights into geopolitical Eurocentrism. ${ }^{38}$ In practice, decentring can mean three different things: moving towards a worldview without a centre, replacing the European centre with a new centre, or replacing the European centre with a multitude of centres. A new centre (let's say an Asian centre) may help overcome Eurocentrism by better recognising the reality of changes in IR, and, in the medium term, may help balance one bias with another one. It does not, however, solve the deeper ethical issues of Eurocentrism, it simply displaces it. And by keeping the related assumption of a 'centred world' intact, it legitimises the (now former) conception of Eurocentrism. It replaces a power-based ethnocentrism, with another power-based ethnocentrism. This particular trend of replacing a parochial centre with another has been lamented by several scholars. Amin warned against the "inverted Eurocentrism" of many third-world culturalisms. ${ }^{39}$ In Chakrabarty's words: "This "first in Europe, then elsewhere" structure of global historical time was historicist; different non-Western nationalisms would later produce local versions of the same narrative, replacing "Europe" by some locally constructed center." ${ }^{30}$ Zeynep Gülşah Çapan and Ayşe Zarakol concur and decry the fact that in the hands of such politicians and their intellectual enablers, postcolonial critiques of universal norms seem to become tools of reasserting essentialist, particularist and nationalistic policies of new imperialisms'. ${ }^{41}$ Sinan Chu provides a recent elaboration on how such critiques of epistemic Eurocentrism can easily and inadvertently turn into a new form of ethnocentrism, as exemplified by his analysis of Sinocentric IR. ${ }^{42}$ It could be argued that Eurocentrism has already been decentred and replaced by a US-centrism (even though the continuity between the two often lumps them together under Western-centrism). In that sense, a new centre seems to inadvertently reproduce Eurocentrism only with a modified form, and does little (but does a little nevertheless) to overcome it: hence the qualification of the 'new centre approach' as one leading to a modified reproduction (that is often accompanied by an intentional power project).

Alternatively, decentring can be done by elaborating a conception of world politics as being without a centre, made of a multitude of provinces, or as being with several centres, in a manner that precludes the rising of a hegemonic centre. The scholarly project of provincialising Europe fits in this understanding. ${ }^{43}$ Provincialising Europe as an epistemic project, however, has been critiqued as a project that aims at 'adding' to the Eurocentric understanding of the world (by bringing to light the contribution of non-Westerners), but without fully deconstructing the very Eurocentric concepts and methodologies used in the process of provincialising. ${ }^{44}$ At the geopolitical level, the multiple centre approach can be conceptualised differently: at times, it may look closer to a new centre approach, if the level of analysis goes down to the regional or local

\footnotetext{
${ }^{37}$ See, for example, Fisher Onar and Nicolaïdis, 'The decentring agenda'; Meghana Nayak and Eric Selbin, Decentering International Relations (New York: Zed Books, 2010); Nilüfer Göle, 'Decentering Europe, recentering Islam', New Literary History, 43:4 (2012), pp. 665-85.

${ }^{38}$ See, for example, Sayyid, A Fundamental Fear.

${ }^{39}$ Amin, Eurocentrism, p. 78.

${ }^{40}$ Dipesh Chakrabarty, Provincializing Europe: Postcolonial Thought and Historical Difference (Princeton, NJ: Princeton University Press, 2000), p. 7.

${ }^{41}$ Zeynep Gülşah Çapan and Ayşe Zarakol, 'Postcolonial colonialism? The case of Turkey', in Charlotte Epstein (ed.), Against International Relations Norms: Postcolonial Perspectives (London: Routledge, 2017), p. 204.

${ }^{42}$ Sinan Chu, 'Whither Chinese IR? The Sinocentric subject and the paradox of Tianxia-ism', International Theory, pp. 1-31, online (25 August 2020), available at: \{https://doi.org/10.1017/S1752971920000214\} accessed 27 February 2021.

${ }^{43}$ Chakrabarty, Provincializing Europe.

${ }^{44}$ Seth, 'Historical sociology and postcolonial theory'; see also Bhambra, 'Historical sociologies, international relations and connected histories'.
} 
level, and each new centre becomes a local hegemon. In such a case, a multiple centre approach tilts more towards modified reproduction. At the international level, a multiple centre approach with no hierarchy between the different centres can look more similar to a no-centre approach, which is the third subtype. This rhizomic, flat, and complex understanding of the world can both be difficult to enact in practice and to theorise in scholarship, but can prove more efficient at bringing about post-Eurocentrism.

While there is an obvious overlap between decentring and dehierarchising, it is important to distinguish them conceptually in order to deconstruct the different logics underpinnings strategies to criticise Eurocentrism. Decentring strategies often include the challenge and erasure of hierarchy (between the centre and the peripheries), but I argue here that decentring do not necessarily challenge the normative hierarchy associated with Eurocentrism. Some decentring projects, implicitly, adopt the hierarchy presented by Eurocentrism (that for instance, put democracy, human rights, sovereignty, and/or capitalism as a the top of the ladder). Other critical approaches to Eurocentrism do, however, challenge this hierarchy, and need to be conceptualised separately. Similarly to the decentring strategy, dehierarchising can take several forms. One is to get rid of a hierarchical worldview altogether. Another is to come up with an alternative, tentatively 'better' hierarchy. A third approach is to invert or adopt a mirror image of the Eurocentric hierarchy.

The latter, the inverted hierarchy, approach is a reactive approach. The logic goes that if Europe or the West is seen as being an immoral actor, the hierarchy of norms that underpins Europe's power should be rejected. The standard is no longer the one against which one should be judged, but rather the standard against which one should rebel. ${ }^{45}$ But it remains the standard. It does not really define a new hierarchy but rather inverts the Eurocentrist one. It is reactive, somewhat arbitrary, and simply values norms because there are not valued in the Eurocentrism worldview. Accordingly, it unintentionally pushes more towards a modified reproduction of Eurocentrism where Eurocentrism remains a standard, and having a hierarchy is justified. The inverted hierarchy approach is often associated with the production of an Occidentalist worldview. Fisher Onar and Nicolaïdis refer to the 'Occidentalist habit of inversing Eurocentric or Orientalist binaries'. ${ }^{46}$

Having a different hierarchy (that may or may not overlap with the Eurocentrist one) is another possible dehierarchising approach. The idea here is to generate a hierarchy of norms that would be self-generated, uncorrupted from the Eurocentrist history and hegemonic spread of the Eurocentric hierarchy. This sometimes takes the form of a romantic view of a so-called indigenous normative worldview, unimpaired by modern (Eurocentric) history. This approach, on the one hand, does not solve the ethical issues related to having a hierarchy of norms (and the hierarchisation of actors that follow suits $)^{47}$ and keep us wondering about the basis under which one hierarchy is seen as more valid than the other. On the other hand, there is also a question regarding whether it is even possible, as one might wonder whether generating such a powerunencumbered normative hierarchy can be done.

Finally, another dehierarchising approach is to conceptualise a non-hierarchical world altogether. This concept brings about a deeper and controversial issue at the intersection between

\footnotetext{
${ }^{45}$ Gülşah Çapan and Zarakol, 'Postcolonial colonialism?', p. 196. See also: 'This, of course, creates a false equivalency whereby democratic flaws in Europe become an excuse for much bigger problems in Turkey, while ironically leaving intact the assumption that Europe is the only proper yardstick by which to measure progress, reproducing one of the main sources of Turkish ontological insecurity.' Zeynep Gülşah Çapan and Ayşe Zarakol, 'Turkey’s ambivalent self: Ontological insecurity in "Kemalism" versus "Erdoğanism", Cambridge Review of International Affairs, 32:3 (2019), p. 276.

${ }^{46}$ Fisher Onar and Nicolaïdis, 'The decentring agenda', p. 291. See also: 'It is clear that neither was the self-consciously pro-Western Republican elite simply imitating the higher Western model, nor similarly was the self-consciously anti-Western Islamist opposition reactionary rejectionist in terms of its assessment of Western civilization. Both camps produced an occidentalist discourse of the West to formulate and legitimate their domestic reform agendas.' Aydin, 'Between Occidentalism and the Global Left', p. 452.

${ }^{47}$ Ann E. Towns and Bahar Rumelili, 'Taking the pressure: Unpacking the relations between norms, social hierarchies, and social pressures on states', European Journal of International Relations, 23:4 (2017), pp. 756-79.
} 
postcolonialism and postmodernism. For postmodern thinkers, it is the only possible condition under which emancipation can happen. For their opponents though, renouncing normative ordering is a dangerous nihilist approach. ${ }^{48}$ For many yet, the question is one of possibility and imagination: how can values be upheld without hierarchy between them, and without recreating inequalities inherent in hierarchies? While this strategy seems closest to be able to overcome Eurocentrism, there are, again, strong questions regarding its practicality.

What emerges from this early analysis is that different approaches regarding the critique of Eurocentrism tend to fall within three realms: one is one of critique and deconstruction (where most of scholarship seems to befall). But when it comes to proposing means to act upon it, anti-Eurocentric reconstruction either leads to the second, an inadvertent modified reproduction of Eurocentrism, or the third, a genuine but possibly impractical overcoming of Eurocentrism. The former seems to be a path traveled far more than the latter.

\section{Turkey and the critique of Eurocentrism as a political praxis}

In order to illustrate in practice how Eurocentrism and anti-Eurocentrism interact, this study now turns to the case of Turkish politics. Because this analysis is mostly interested in practitioners' engagement and critique of Eurocentrism, the following analysis focuses primarily on geopolitical Eurocentrism, also it is sometimes intimately tied with a critique of epistemic Eurocentrism. Turkey figures prominently in discussions of Eurocentrism. This is mainly due to Turkey's unique historical positionality vis-à-vis the expansion of European powers: Turkey (together with its Ottoman predecessor) has engaged in a process of Westernisation that tested the universalist claims of European identity and values; it has never been colonised and could rely on a glorious past to challenge some Eurocentric assumptions of the world order they were situated in; it has also been 'defeated' by the West, and hence in need of renegotiating their own identity in the world order; Turkish identity construction has evolved in the context of liminality and stigmatisation; it has also partially adopted Eurocentric assumptions as a means to get recognition and status; and it has played an important role in the construction of a European identity. ${ }^{49}$ Therefore unsurprisingly, a number of scholars working on Turkey have made their mark on the critical IR literature. ${ }^{50}$

\footnotetext{
${ }^{48}$ Sebastiano Maffetone, 'How to avoid the liaison dangereuse between post-colonialism and postmodernism', Philosophy \& Social Criticism, 37:4 (2011), pp. 493-504.

${ }^{49}$ Zarakol, After Defeat; Bahar Rumelili, 'Turkey: Identity, foreign policy, and socialization in a post-enlargement Europe', European Integration, 33:2 (2011), pp. 235-49; Bahar Rumelili, 'Liminal identities and processes of domestication and subversion in International Relations', Review of International Studies, 38:2 (2012), pp. 495-508; Lerna Yanık, 'Constructing Turkish "exceptionalism": Discourses of liminality and hybridity in post-Cold War Turkish foreign policy', Political Geography, 30:2 (2011), pp. 80-9.

${ }^{50}$ They notably include Ayşe Zarakol, Pınar Bilgin, Zeynep Gülşah Çapan, Bahar Rumelili, Deniz Kuru, and Ersel Aydınlı, others cited in this study, and more. Zarakol, After Defeat; see also, Ayşe Zarakol, 'What made the modern world hang together: Socialization or stigmatization?', International Theory, 6:2 (2014), pp. 311-32; Janice Bially Mattern and Ayşe Zarakol, 'Hierarchies in world politics', International Organization, 70:3 (2016), pp. 623-54; Pinar Bilgin, 'Thinking past “Western” IR?', Third World Quarterly, 29:1 (2008), pp. 5-23; Pınar Bilgin, 'Turkey's changing security discourses: The challenge of globalisation', European Journal of Political Research, 44:1 (2005), pp. 175-201; Pinar Bilgin, “Only strong states can survive in Turkey's geography”: The uses of "geopolitical truths” in Turkey', Political Geography, 26:7 (2007), pp. 740-56; Gülşah Çapan, Re-Writing International Relations; Gülşah Çapan and Zarakol, 'Postcolonial colonialism?'; Gülşah Çapan, 'Enacting the international/reproducing Eurocentrism'; Gülșah Çapan and Zarakol, 'Turkey’s ambivalent self; Gülşah Çapan, 'Construction of the non-West'; Bahar Rumelili, 'Constructing identity and relating to difference: Understanding the EU's mode of differentiation', Review of International Studies, 30:1 (2004), pp. 27-47; Bahar Rumelili, 'Liminality and perpetuation of conflicts: Turkish-Greek relations in the context of community-building by the EU', European Journal of International Relations, 9:2 (2003), pp. 213-48; Viatcheslav Morozov and Bahar Rumelili, 'The external constitution of European identity: Russia and Turkey as Europe-makers', Cooperation and Conflict, 47:1 (2012), pp. 28-48; Rumelili, 'Turkey'; Towns and Rumelili, 'Taking the pressure'; Kuru, 'Historicising Eurocentrism'; Deniz Kuru, 'Homegrown theorizing: Knowledge, scholars, theory', All Azimuth: A Journal of Foreign Policy and Peace, 7 (2017), pp. 69-86; Ersel Aydınlı and
} 
Of particular interest here is the fact that a wide range of actors in Turkey today have a certain level of awareness regarding the underpinnings of Eurocentrism, and can typically articulate a form of anti-Eurocentric discourse. This includes the elite (intellectuals, scholars, and the political elite) but also more broadly the population of Turkey. In fact, the adoption of a strong anti-Eurocentric discourse within the ruling party (the AKP) resonates with the electorate at large, even among segments typically opposed to the AKP's political programme. ${ }^{51}$ Within the AKP, the most vocal voices that have tackled Eurocentrism include: President Recep Erdoğan who has been the single most influential voice in Turkish domestic and foreign policy since his ascendency as prime minister in 2003 and president since 2014; ${ }^{52}$ Ahmet Davutoğlu (Turkey's Minister of Foreign Affairs from 2009 to 2014, and Turkey's Prime Minister from 2014 to 2016) and Ibrahim Kalın (Turkish presidential press secretary since 2015), who were both intellectualising figures in the party with a scholarly background and publications that, at times, flirt with insights from Global IR and postcolonial literature. In addition, over the last 15 years, a scholarly enterprise working in the service of the AKP has emerged, and some of its writers have used Eurocentrism and anti-Eurocentrism as part of their analysis. ${ }^{53}$ Beyond the top-level of the intellectual and political elite currently empowered, it is also possible to identify, among lower ranks of people working in the governmental bureaucracy, many people who would routinely articulate anti-Eurocentric tropes and use some of its vocabulary. ${ }^{54}$

The specific form of anti-Eurocentric critique expressed by the Turkish ruling elite has many dimensions. As highlighted by the existing literature on anti-Westernism in the AKP rhetoric, much of the critique is counter-hegemonic, and critiques Western power. It challenges the current order, and calls for equality among nations, or at least more space for rising middle powers. ${ }^{55}$ This is in essence the core of Erdoğan's motto 'the world is bigger than five' focusing on the unfair amount of power held by the five permanent members at the UN Security Council. The UN is indeed constructed in Turkish discourses as a 'Western' organisation, one that reflects mostly Western interest, and can therefore be seen as an expression and institutionalisation of geopolitical Eurocentrism. ${ }^{56}$ As illustrated by Gülşah Çapan and Zarakol, many of the publications coming out of the think tank SETA engage in a defence of the foreign policy of the AKP leadership that is rooted in critiques of Eurocentrism. ${ }^{57}$ In their words, these publication are an attempt 'to break free of the impositions of the hierarchical nature of the international system .... As such, there is a story of resistance and hegemony being told here whereby Turkey and the AKP government are located within the resistance. ${ }^{58}$ This counter-hegemonic form of anti-Eurocentrism is often discussed as being already realised and successful, or inevitably about to be so. In 2014, Erdoğan affirmed:

\footnotetext{
Julie Mathews, 'Periphery theorising for a truly internationalised discipline: Spinning IR theory out of Anatolia', Review of International Studies, 34:4 (2008), pp. 693-712; Ersel Aydınlı and Gonca Biltekin, 'Widening the world of IR: A typology of homegrown theorizing', All Azimuth: A Journal of Foreign Policy and Peace, 7 (2017), pp. 45-68.

${ }^{51}$ Senem Aydın-Düzgit, 'De-Europeanisation through discourse: A critical discourse analysis of AKP's election speeches', South European Society and Politics, 21:1 (2016), pp. 45-58 (p. 56).

${ }^{52}$ Aydın-Düzgit, 'De-Europeanisation through discourse'; Alper Kaliber and Esra Kaliber, 'From de-Europeanisation to anti-Western populism: Turkish foreign policy in flux', The International Spectator, 54:4 (2019), pp. 1-16; Berdal Aral, “'The world is bigger than five”: A salutary manifesto of Turkey's new international outlook', Insight Turkey, 21:4 (2019), pp. 71-95.

${ }^{53}$ Gülşah Çapan and Zarakol, 'Postcolonial colonialism?'.

${ }^{54}$ Juliette Tolay, 'Turkey's critical Europeanization: "For the European Union, despite the European Union"?', in K. B. Kanat, K. Üstün, and N. Yilmaz (eds), History, Politics and Foreign Policy in Turkey (Ankara: SETA Publications, 2011), pp. 194-210.

${ }^{55}$ Adar and Yenigün, 'A Muslim counter-hegemony?', p. 9; Kaliber and Kaliber, 'From de-Europeanisation to anti-Western populism', p. 5.

${ }^{56} \mathrm{Aral}$, “The world is bigger than five", p. 80.

${ }^{57}$ Gülşah Çapan and Zarakol, 'Postcolonial colonialism?'.

${ }^{58}$ Gülşah Çapan, 'Enacting the international/reproducing Eurocentrism', p. 662.
} 
Turkey is now a country whose agenda is not determined, but who determines her own agenda, this is the difference we have. For years they have bowed down in front of the West, this is what they did. What did the West do? It gave orders, and they obeyed those orders. But now there is no such situation. We sit down, we talk, we take our decisions, but we make the decisions, this is the Turkey that there is now. ${ }^{59}$

Three years earlier, Davutoglu had already announced the dawn of geopolitical Eurocentrism:

Now we are living in such an accelerated flow of history, we cannot be static. We cannot have prejudices in our minds, we cannot have stereotypes, if we want to understand this new global transformation. How should we address to this? First of all, there is a political change. There is no - like Cold War - a Eurocentric or Euroatlantic plus Soviet Union center of world politics anymore. There are new rising powers. ${ }^{60}$

While Ibrahim Kalın also expressed concerns about the persistence of Eurocentrism (there is 'an immense self-confidence and hubris to build a new world based on a Eurocentric worldview'), ${ }^{61}$ he concurred with his party leadership to predict the demise of Eurocentrism: 'Eurocentrism is still very much alive in the arteries of the current world system. ... But this is a self-defeating approach.'62

Of particular interest here is the fact that this AKP challenge of Eurocentrism is articulated around two main conceptions: one is to claim moral superiority over the West, the other is to affirm the existence of other centres beyond Europe. Kaliber and Kaliber have analysed how the AKP's foreign policy has been 'characterized by a vehement anti-Westernism, through which the superior Islamic Turkish self is constructed against the inferior Western other'.63 Senem Aydin-Düzgit similarly finds in her analysis that 'Europe/the EU is negatively represented in Erdoğan's discourse [and] it is constructed as an inferior entity to Turkey in both political and economic terms. ${ }^{64}$ And in turn, this claim of moral superiority paves the way for the affirmation of the existence of multiple centres beyond the European/Western centre. This decentring strategy operates through three different images: one is where Turkey becomes the champion of the periphery against the centre; ${ }^{65}$ the second is when Turkey realises the existence of other centres beyond Europe, opening up its foreign policy horizon; ${ }^{66}$ the third is when Turkey itself becomes a centre, as when Davutoglu defines Turkey as a 'central country' on its own standing. ${ }^{67}$

\section{Illustration of the inadvertent reproduction of Eurocentrism in the field of migration in Turkey}

These mechanisms of reproduction through a critique of Eurocentrism can be illustrated in greater details when diving in the specifics of Turkish migration policy as a subset of its foreign

\footnotetext{
${ }^{59}$ Erdoğan speech at Elazığ, 6 March 2014, cited in Aydın-Düzgit, 'De-Europeanisation through discourse', p. 51.

${ }^{60}$ Ahmet Davutoğlu, 'Speech Delivered by H. E. Ahmet Davutoğlu, Minister of Foreign Affairs of Turkey, in the University of London School of Economics and Political Science, 7 March 2013, London', available at: \{http://www.mfa.gov.tr/speechdelivered-by-h_e_-ahmet-davutoglu_-minister-of-foreign-affairs-of-turkey_-in-the-university-of-london-school-of-economics.en.mfa\} accessed on 24 January 2021. Errors in the original, emphasis added

${ }^{61}$ İbrahim Kalın, 'The age of unreason', Daily Sabah (2 February 2018), available at: $\{$ https://www.dailysabah.com/columns/ibrahim-kalin/2018/02/24/the-age-of-unreason\} accessed 24 January 2021.

${ }^{62}$ İbrahim Kalın, 'The age of terrorism and hypocrisy', Daily Sabah (14 June 2017), available at: \{https://www.dailysabah. com/columns/ibrahim-kalin/2017/06/14/the-age-of-terrorism-and-hypocrisy\} accessed 24 January 2021.

${ }^{63}$ Kaliber and Kaliber, 'From de-Europeanisation to anti-Western populism', p. 3.

${ }^{64}$ Aydin-Düzgit, 'De-Europeanisation through discourse', p. 54.

${ }^{65} \mathrm{Aral}$, “The world is bigger than five”, p. 78 (the centre-periphery vocabulary is an extension of an argument made about domestic Turkish politics, as developed by Şerif Mardin in 1973).

${ }^{66}$ Kaliber and Kaliber, 'From de-Europeanisation to anti-Western populism', p. 7.

${ }^{67}$ Ahmet Davutoglu, Stratejik Derinlik (Küre Yayınları, 2001).
} 
policy. Many pieces of literature have been written over the years to discuss Turkey's immigration policies and their evolution in the twenty-first century. ${ }^{68}$ Looking at the intersection of foreign policies and immigration policies, it is obvious that Turkey's relationship with the European Union plays an important role - albeit often in unexpected ways - in explaining the different policies put in place. ${ }^{69}$ This has been true during the first AKP years of negotiations towards Turkey's membership in the EU (roughly 2002-08), but it has continued beyond, including during the 2015-16 European crisis over refugee management and, since 2011, the mass exodus of Syrian refugees, two-thirds of whom have found refuge in Turkey, making Turkey the country hosting the largest refugee population since $2015 .^{70}$

On the one hand, it is particularly interesting to think through Turkish migration policy because by and large, most of the policy development that has happened in the twenty-first century regarding migration management has been done in a Eurocentric framework, through the double processes of Europeanisation of Turkish policies, ${ }^{71}$ and EU externalisation of immigration policies. ${ }^{72}$ The process of Europeanisation - typically defined as the adoption by candidate countries to the European Union of the existing norms and rules of the union to satisfy conditionality requirements - means the implementation of policies and adoption of norms that are defined by Europe, typically without input from candidate countries. While this process can be understood as one of applying traditional membership rules, these policies and norms pushed by Europeanisation follow a traditional Eurocentric template of: (1) being defined one-sidedly by European actors; but (2) thought of as having a universal character; and (3) assumed to be eventually uncritically adopted by any 'forward-looking' actors in the world who will follow Europe's 'lead'. ${ }^{73}$ The criticism of the Eurocentrism of Europeanisation is not so much grounded in the idea of Europeanisation as a means to define group membership, but more in the manner in which it has been implemented: an 'unreflexive' intersubjective process in which EU actors act as 'teachers' and 'gatekeepers' and the Europeanising side act, willingly or not, as the 'recipient'

\footnotetext{
${ }^{68}$ Ahmet İçduygu and Damla Aksel, 'Turkish migration policies: A critical historical perspective', Perceptions: Journal of International Affairs, 18:3 (2013), pp. 167-90; Juliette Tolay, 'Discovering immigration into Turkey: The emergence of a dynamic field', International Migration, 53:6 (2015), pp. 57-73; Ilker Ataç, Gerda Heck, Sabine Hess, Zeynep Kaşl1, Philipp Ratfisch, Cavidan Soykan, and Bediz Yllmaz, 'Contested b/orders: Turkey's changing migration regime: An introduction', Movements, 3:2 (2017), pp. 9-21.

${ }^{69}$ See, for instance, Kemal Kirişci, 'The question of asylum and illegal migration in European Union-Turkish relations', Turkish Studies, 4:1 (2003), pp. 79-106; Ahmet İçduygu and Ayşen Üstübici, 'Negotiating mobility, debating borders: Migration diplomacy in Turkey-EU relations', in H. Schwenken and S. Ruß-Sattar (eds), New Border and Citizenship Politics (London: Palgrave Macmillan, 2014), pp. 44-59; Gerda Heck and Sabine Hess, 'Tracing the effects of the EU-Turkey deal: The momentum of the multi-layered Turkish border regime', Movements, 3:2 (2017), pp. 35-58.

${ }^{70}$ UNHCR, 'Syria Regional Refugee Response' (13 January 2021), available at: \{http://data2.unhcr.org/en/situations/syria accessed on 24 January 2021.

${ }^{71}$ Ahmet İçduygu, 'EU-ization matters: Changes in immigration and asylum practices in Turkey', in T. Faist and A. Ette (eds), The Europeanization of National Policies and Politics of Immigration (London: Palgrave Macmillan, 2007), pp. 201-22; Nurcan Özgur Baklacıoglu, 'Building “Fortress Turkey”: Europeanization of asylum policy in Turkey', The Romanian Journal of European Studies, 7-8 (2009), pp. 103-18; Saime Özçürümez and Nazlı Şenses, 'Europeanization and Turkey: Studying irregular migration policy', Journal of Balkan and Near Eastern Studies, 13:2 (2011), pp. 233-48; Juliette Tolay, 'Turkey's "critical Europeanization": Evidence from Turkey's immigration policies', in S. Paçacı Elitok and T. Straubhaar (eds), Turkey, Migration and the EU: Potentials, Challenges and Opportunities (Hamburg: Hamburg University Press, 2012), pp. 39-62; Alexander Bürgin, 'Why the EU still matters in Turkish domestic politics: Insights from recent reforms in migration policy', South European Society and Politics, 21:1 (2016), pp. 105-18.

${ }^{72}$ Sandra Lavenex and Emek M. Uçarer, 'The external dimension of Europeanization: The case of immigration policies', Cooperation and Conflict, 39:4 (2004), pp. 417-43; Heck and Hess, 'Tracing the effects'; Ayşen Üstübici, 'The impact of externalized migration governance on Turkey: Technocratic migration governance and the production of differentiated legal status', Comparative Migration Studies, 7:46 (2019), pp. 1-18.

${ }^{73}$ Trine Flockhart, 'Europeanization or EU-ization? The transfer of European norms across time and space', Journal of Common Market Studies, 48:4 (2010), pp. 787-810.
} 
of EU standards. ${ }^{74}$ In other words, it is the assumption of Europeanisation as the only possible and desirable future for the EU and Turkey, without expectation of Turkish contribution to the definition of the EU that creates an environment ripe for Eurocentrism.

The process of externalisation (whereby the EU asks neighbouring countries to enact policies defined by the EU - such as certain types of border control or visa policies) has less of a universal claim attached to it, but follows another typical Eurocentric template, whereby Europe's power is used to request third countries to implement policies that serve European's interests. ${ }^{75}$ In the second decade of the twenty-first century, Europeanisation became less prominent in Turkey's migration governance (following the gradual and mutual abandonment of the Turkey's EU accession process), but in the field of migration, externalisation continued to played an increasingly important role (as embodied in the EU-Turkey admission agreement of 2013 and the EU-Turkey statement of 2016, aka refugee deal, discussed below).

On the other hand, the study of Turkish migration policy is also warranted because the Turkish ruling elite has used migration as a tool to engage in anti-Eurocentrism by claiming moral superiority and advocating a post-Western world. This has been even more so true following the migration management crisis of 2015. The following quote from Erdoğan is illustrative:

I actually find the whole Western world guilty in this regard. The Western-centred world is behind us; the new world is multi-centred. The Western countries that set the criteria of freedom after World War II, unfortunately, are now turning their backs on these values. It is not only refugees who are drowning in the Mediterranean - our very humanity is drowning in the Mediterranean. The values that make us who we are have drowned in the Mediterranean. Every refugee left to their fate at the gates of Europe, or even deliberately sunk in their boats - left to die - reflect this very reality. ${ }^{76}$

Through this representative quote, it becomes clear that the migration crisis is providing arguments based on social realities and ethics that enables and strengthens Erdoğan's countering of Eurocentrism. ${ }^{77}$

However, despite this criticism of Eurocentrism, Turkish authorities have, on several occasions, engaged in inadvertent reproductions of Eurocentrism. This case study is presented here heuristically as a means to illustrate the different types and ways that anti-Eurocentrism (and its reproduction) can be conceptualised, and to understand the broader role the critique and reproduction of Eurocentrism play in political discourses and policies.

\section{Illustration 1: Critical Europeanisation as a process of decentring with a new centre}

Even during the time of rapid Europeanisation mentioned above, the process did not unfold uncritically. All throughout this period, resistance has occurred: it happened both in discourses

\footnotetext{
${ }^{74}$ Key terms borrowed from the analyses of Federica Bicchi, “Our size fits all”: Normative power Europe and the Mediterranean', Journal of European Public Policy, 13:2 (2006), pp. 286-303, and Katherine Graney, Russia, the Former Soviet Republics, and Europe since 1989: Transformation and Tragedy (Oxford: Oxford University Press, 2019).

${ }^{75}$ As illustrated in the literature, while externalisation is a projection of Eurocentric interests and policies upon third countries, it is also an opportunity for these countries to exert agency and extract certain benefits in return. See Martin Lemberg-Pedersen, 'Manufacturing displacement: Externalization and postcoloniality in European migration control', Global Affairs, 5:3 (2019), pp. 247-71. See also Heck and Hess, 'Tracing the effects', p. 52.

${ }^{76}$ Deniz Sert and Didem Danış, 'Framing Syrians in Turkey: State control and no crisis discourse', International Migration, online (23 July 2020), pp. 1-18 (p. 11), available at: \{https://onlinelibrary.wiley.com/doi/abs/10.1111/imig.12753\} accessed on 24 January 2021. See also Özgür Balkılıç and Fatma Armağan Teke Lloyd, 'Does Islamic inclusion of Syrians represent a real challenge to Europe's security approach?: Dilemmas of the AKP's Syrian refugee discourse', Turkish Studies, online (5 June 2020), available at: $\{$ https://www.tandfonline.com/doi/abs/10.1080/14683849.2020.1774372?journalCode=ftur20\} accessed 24 January 2021.

${ }^{77}$ See also Zeynep Yanaşmayan, Ayșen Üstübici, and Zeynep Kaşl, 'Under the shadow of civilizationist populist discourses: Political debates on refugees in Turkey’, New Diversities, 21:2 (2019), pp. 37-51 (p. 48).
} 
and in the selection of European policies and demands to put in place. Turkish authorities have engaged in a process of 'critical Europeanisation', whereby European norms are being accepted as a goal, but European policies and practices are criticised for being hypocritical, unfair, imbalanced, inconsistent, securitised, and burdening. ${ }^{78}$ These multilayered criticisms can be interpreted as a critique of Eurocentrism. Accordingly, many of the policy reforms done between 2002 and 2008, were done either reluctantly (as a necessary 'price to pay') or enthusiastically, as a means to prove to the Europeans that Turkey could adopt 'better' policies than the ones put in place by Europe. Pride was generated out of the idea of being 'more European than the Europeans $^{79}$ (that is, putting in place migration policies that are respectful of migrants rights advocated by European actors, in contrast to the restrictive and abusive policies put in place by these same actors).

This thought process of being 'more Europeans than the Europeans', I argue, is illustrative of the decentring type of anti-Eurocentrism. The conceptualisation here is to say that Europe does not deserve to be considered at the centre (or at the top) of a normative order of migration governance. However, the idea is not so much that there should be no centre, or that there should be recognition of multiple centres, but rather Turkey might be the one replacing Europe at this position. Accordingly the Eurocentric view of migration governance is reproduced in this critique, although it does replace Europe with Turkey as being the new 'notable and noble' centre.

This decentring (away from Europe) and recentring (around Turkey) process is built upon the combination of several tropes. One is to argue that Europe does not deserve to be at the centre because it is now decaying, it does not hold to its own standard and is therefore hypocritical. ${ }^{80}$ It is most clearly stated by Erdoğan in 2015:

Today there are around two millions siblings within our borders who fled from Syria and Iraq ... Two millions here, 130,000 in the whole of Europe. Where is our commitment to human rights, the Universal Declaration of Human Rights? Wasn't it you who were protecting the oppressed? What happened to the European Union acquis? Where are you? ${ }^{81}$

This first trope is then complemented by the affirmation that Turkey is doing better than the European, if not doing 'the best', and deserves to be seen at the centre. Consider the following quotes for illustration:

For the last four years, by adopting over 2 million Syrian and Iraqi brothers, Turkey has gone beyond doing her neighborly duties and saved the honour of humanity. (Erdoğan in 2015) ${ }^{82}$

There is panic in Europe. Xenophobia is on the rise. There were 871 attacks against refugees houses in Germany only in the last year. Belgium, Netherlands is no different. Denmark passed a new law to confiscate their valuables. Britain puts a red bracelet to them. We don't do any of these. We have legal, historical, conscientious responsibility. We manage this process in the best way. (Atay Uslu, Member of Parliament for Antalya in 2016) ${ }^{83}$

\footnotetext{
${ }^{78}$ Tolay, 'Turkey's “critical Europeanization”: Evidence'; Tolay, 'Turkey's critical Europeanization: "For the European Union, despite the European Union"?'.

${ }^{79}$ Juliette Tolay, 'Turkey's critical Europeanization: "For the European Union, despite the European Union"?'.

${ }^{80}$ Balkılıç and Teke Lloyd, 'Does Islamic inclusion of Syrians represent', p. 3; Rabia Karakaya Polat, 'Religious solidarity, historical mission and moral superiority: construction of external and internal "others” in AKP's discourses on Syrian refugees in Turkey', Critical Discourse Studies, 15:5 (2017), pp. 500-16 (p. 510).

${ }^{81}$ Polat, 'Religious solidarity, historical mission and moral superiority', p. 510.

${ }^{82}$ Quoted in Yanaşmayan, Üstübici and Kaşlı, 'Under the shadow of civilizationist populist discourses', p. 47.

${ }^{83}$ Quoted in Polat, 'Religious solidarity, historical mission and moral superiority', p. 509.
} 
After describing the negative treatment refugees go through in Europe, an AKP MP states, 'in the past, they used to come to Turkey to investigate 'human rights'. Now Turkey is the best with regards to human rights. (Said Yuce, Member of Parliament for Isparta in 2016) ${ }^{84}$

Implicit in these statements is an acceptance of the Eurocentric assumption that Europe was ahead, but now Turkey has 'caught up'. The linear view of progress as defined by Europe is here kept intact, only the temporal gap between Europe and Turkey has disappeared, and Turkey is now conceived as being ahead. This 'new centre' form of inadvertent reproduction raises also another question. When Europe was conceived at the centre, it was perceived as being hegemonic and abusive of its power. If Turkey is now the new centre, what about the risks of Turkey developing its own hegemony? The potential for abuse by the new centre is particularly acute when one observe Erdoğan's frequent threats (and enactment) to send refugees to Europe. ${ }^{85}$ While these threats can be interpreted as a sign of weakness from Turkey (who might not really be the new centre), it can also be interpreted as the unfortunate consequence of newfound power, that opens space for abuse, arbitrariness, and hypocrisy. In turns, this undermines the credibility of the moral superiority claimed earlier that was one the pillars of the AKP's critique of Eurocentrism.

\section{Illustration 2: Continued externalisation as a process of superficial critique}

Starting from 2008, the process of Europeanisation progressively disappears as Turkey's EU membership faced an increasing number of roadblocks, and both Turkish and EU actors become increasingly disinterested in this project. Accordingly, Turkish criticism of Europe becomes straightforward and vocal. ${ }^{86}$ In the field of migration, the internalisation of norms and socialisation through the process of Europeanisation (and the impact of other international actors) ${ }^{87}$ would actually continue to have an impact on policy reform until the adoption of the Law on Foreigners and International Protection of $2014 .^{88}$ But beyond this important policy change, the EU-Turkey relations during the period witness a clear turn toward a more transactional mode, based less on ideological convergence and more on conjunctural congruent interests. A couple of landmark agreements on migration issues mark this period: the first one is the signature of the readmission agreement in December 2013, ${ }^{89}$ the second is the EU-Turkey deal of March $2016 .^{90}$ One of the characteristics of these arrangements is that they require Turkey to act as the border guard of the EU/Schengen borders (in exchange of other benefits). ${ }^{91}$ While the readmission agreement recognises some level of reciprocity (that is, irregular migrants crossing from Europe to Turkey should be readmitted to Europe - a reciprocity that carries little relevance in practice), there is no principle of reciprocity in the EU-Turkey deal. Turkey is therefore required to do the EU's job of border protection and hence protect specific and parochial EU interests that do not have universal claims. These agreements therefore represent a very stark

\footnotetext{
${ }^{84}$ Quoted in ibid., p. 510.

${ }^{85}$ Balkılıç and Teke Lloyd, 'Does Islamic inclusion of Syrians represent', p. 3.

${ }^{86}$ Kaliber and Kaliber, 'From de-Europeanisation to anti-Western populism'.

${ }^{87}$ Shoshana Fine, Borders and Mobility in Turkey: Governing Souls and States (London: Palgrave Macmillan, 2018).

${ }^{88}$ Bürgin, 'Why the EU still matters'.

${ }^{89}$ See full text of agreement at: \{https://eur-lex.europa.eu/legal-content/EN/TXT/PDF/?uri=CELEX:22014A0507(01) \&from=EN $\}$ accessed 24 January 2021.

${ }^{90}$ See full text of agreement at: $\{$ https://www.consilium.europa.eu/en/press/press-releases/2016/03/18/eu-turkey-statement/ $\}$ accessed 24 January 2021.

${ }^{91}$ These other benefits can be directly tied to the migration governance (such as the payment of three billion euros renewed once - envisioned by the EU-Turkey deal). Most benefits though are unrelated political good negotiated: such as (a roadmap towards) a visa liberalisation agreement for Turkish citizens in Turkey (tied both to the readmission agreement and the EU-Turkey deal), a renegotiation of the Customs Union, or the opening of negotiations of a chapter towards Turkey's membership to the EU (in the EU-Turkey deal).
} 
form of externalisation of EU policies and Eurocentrism. Even members of the opposition in the Turkish parliament were aware of this core danger of the EU-Turkey deal, and had argued in the Grand Assembly: '[W]e all know what it means to accept an agreement that unilaterally seeks the interests of the European Union. This is similar to the capitulations during the last period of the Ottoman Empire. Turkish people will not accept this. ${ }^{, 92}$ Yet, Turkey accepted it. How can we explain that Turkey accepted to implement such a Eurocentric agreement? How can we explain that the main architect of this Eurocentric EU-Turkey deal on the Turkish side (Ahmet Davutoglu, during his last weeks as prime minister) is also a vocal and educated voice on the critique of Eurocentrism?

One way to understand this unwitting Eurocentrism is to situate it in a 'pragmatism' vs 'idealism' frame. In this understanding, anti-Eurocentrism is an idealist goal, which can be balanced against more pragmatic (often material) goals. ${ }^{93}$ Because the readmission agreement and the EU-Turkey deals had specific promises attached, these agreements can be justified as a compromise. The EU-Turkey deal also led to an immediate reduction of the number of dangerous sea crossings on the Aegean, which is mainly how Erdoğan was able to morally justify his cooperation with Europe: 'We are moving forward in cooperation with the EU toward the refugee crisis. With the goal of stopping fatalities in the Aegean sea, we managed to reduce the number of irregular migrants from 7,000 per day as of October 2015 to 50 per day in the last months. ${ }^{94}$ Another way to think about it - and one that finds evidence in the rhetoric adopted by President Erdoğan - is to present these agreements not as a proof of cooperation or a favour to Europe, but rather as a shrewd way to play Europe's own (immoral and unfair) game and winning at the game. ${ }^{95}$ However, this reading of the situation confuses anti-Eurocentrism with anti-Europe feelings and actions, prevents Turkey from claiming the higher ground it was arguing when engaging in critical Europeanisation, and underestimate the power (or the cost) of Eurocentrism for a country like Turkey. Accordingly, this inadvertent Eurocentrism can be classified as a rhetorical and superficial critique. It highlights the extent to which the understanding and/or commitment towards anti-Eurocentrism is weak, and can easily be abandoned, leading to a reproduction of Eurocentrism.

Indeed, understood through the lens of Eurocentrism, the real cost for Turkey of implementing the EU-Turkey deal is not the cost of increasing border guard capabilities or the cost of hosting additional Syrian refugees on its territory. Rather the main cost is the long-term consequence of socially constructing an EU border that excludes Turkey, and definitely eliminates the prospect of Turkey's EU membership. As put by Didem Danış: 'The EU will never accept as a member a country which has turned into a buffer zone at such a high cost. ${ }^{96}$ It is also the cost of justifying through practice the primacy of EU interests in migration governance, hence making it more difficult in the future to challenge the Eurocentric order. Even more importantly, it is the cost of implementing a deal that uses migrants and refugees as bargaining chips, hence accentuating migrants' vulnerability and precarity, ${ }^{97}$ as well as discrediting the

\footnotetext{
${ }^{92}$ Quoted in Ipek Demirsu and Meltem Muftuler-Bac, 'The Turkish-EU Cooperation on the Refugee Crisis: The Turkish Perceptions in the Parliamentary Debates', PACO Working Paper No. 7, p. 11, available at: \{https:/ghum.kuleuven.be/ggs/ research/paco/working-papers/pacowp07.pdf\} accessed 24 January 2021.

${ }^{93}$ Menderes Çınar, 'Turkey's “Western” or “Muslim” identity and the AKP's civilizational discourse', Turkish Studies, 19:2 (2018), pp. 176-97.

${ }^{94}$ Erdogan speech at the UN in 2016, 'Avrupa Birliği ile mülteci krizine karşı işbirliği içinde hareket ediyoruz. Ege Denizindeki ölümlerin önünü almak amacıyla 2015 Ekim ayında günlük 7 bin olan düzensiz göç rakamının son aylarda 50'ye kadar düşmesini sağladık' [author's translation], available at: \{https://www.tccb.gov.tr/konusmalar/353/52364/birlesmis-milletler-71-genel-kurulunda-yaptiklari-konusma.html\} accessed 24 January 2021.

${ }^{95}$ See, for instance, Gizem Sade, 'Suriyeliler konusunda destek vermezlerse açarız sınırları yürüsünler Avrupa'ya', Euronews (26 October 2019), available at: \{https://tr.euronews.com/2019/10/26/erdogan-150-saat-sonunda-burasi-teroristlerden-temizlenmezse-butun-temizligi-biz-yapacagiz $\}$ accessed on 24 January 2021.

${ }^{96}$ Didem Danıs, 'A new period in Turkish migration policy: Syrian refugees as a foreign policy instrument', SAHA, 1 (2016), p. 26.

${ }^{97}$ Kim Rygiel, Feyzi Baban, and Suzan Ilcan, 'The Syrian refugee crisis: The EU-Turkey “deal” and temporary protection', Global Social Policy, 16:3 (2016), pp. 315-20; Heck and Hess, 'Tracing the effects'.
} 
'responsible' and 'benevolent' image the Turkish government has worked so hard to build over the last few years. ${ }^{98}$

\section{Third type: Humanitarian discourse as a form of inverted hierarchy}

Underlying many of the policy decisions over the last twenty years is another way in which Eurocentrism is both criticised and inadvertently reproduced. It is a much diffused and largely discursive (although with real policy implications) form of governance regarding migration and refugees in Turkey. There are several interpretations of it, but they all point to the fact that Turkey's apparent generous approach towards migration is based on alternatives to a rights-based approach. There have been discussions regarding the fact that Turkey does not recognise 'refugee' status to Syrian asylum seekers in Turkey, nor to any non-European asylum seeker. Syrians are mostly referred to as 'guests'. Based on Turkey's continuous use of the geographical limitation of the 1951 Geneva Convention, only individuals coming from countries that are members of the Council of Europe can be recognised as 'refugees'. Non-European asylum seekers can now be recognised as 'conditional refugees'. As for Syrians, they fall under the 'temporary protection' status, which carries some similarities with a refugee status, but is 'temporary' in nature and does not provide any long-term perspective. ${ }^{99}$

Accordingly, the common language used to refer to Syrians by Turkish authorities (who cannot use the term 'refugee') is 'guest' or 'brother'. This language is not innocent. It is reflective on a Turkish approach to asylum governance that emphasises kinship, hospitality, emotions, generosity, religious solidarity, and civilisational values, rather than a rights-based approach that is considered 'European'. ${ }^{100}$ As described by Rabia Karakaya Polat: 'Discourses on refugees are mostly based upon religious solidarity and historical responsibility arising from the Ottoman past, rather than a universal human rights approach. ${ }^{101}$ The Turkish leadership uses this cultural and humanitarian language as a means to motivate and bring about feelings of duty towards refugees. To some extent it has been successful, allowing Turkey to absorb almost four million refugees in a few years with limited backlash. However, it leaves refugees

\footnotetext{
${ }^{98}$ Ahmet Davutoğlu, 'Turkey’s humanitarian diplomacy: Objectives, challenges and prospects', Nationalities Papers, 41:6 (2013), pp. 865-70; Özden Zeynep Oktav and Aycan Çelikaksoy, 'The Syrian refugee challenge and Turkey's quest for normative power in the Middle East', International Journal, 70:3 (2015), pp. 408-20; Juliette Tolay, 'Mass migration and images of state power: Turkey's claim to the status of a responsible power', Rising Powers Quarterly, 1:2 (2016), pp. 135-49; Umut Korkut, 'Pragmatism, moral responsibility or policy change: The Syrian refugee crisis and selective humanitarianism in the Turkish refugee regime', Comparative Migration Studies, 4:2 (2016), pp. 1-20; Nefise Ela Gökalp Aras and Zeynep Mencütek, 'Evaluation of irregular migration governance in Turkey from a foreign policy perspective', New Perspectives on Turkey, 59 (2018), pp. 63-88.

${ }^{99}$ Metin Çorabatır, 'The Evolving Approach to Refugee Protection in Turkey: Assessing the Practical and Political Needs', Migration Policy Institute (September 2016), available at: \{https://www.migrationpolicy.org/research/evolving-approach-refugee-protection-turkey-assessing-practical-and-political-needs\} accessed 24 January 2021; Feyzi Baban, Suzan Ilcan, and Kim Rygiel, 'Syrian refugees in Turkey: Pathways to precarity, differential inclusion, and negotiated citizenship rights', Journal of Ethnic and Migration Studies, 43:1 (2017), pp. 41-57; Laura Batalla and Juliette Tolay, 'Toward Long-Term Solidarity with Syrian Refugees? Turkey’s Policy Response and Challenges', Atlantic Council Report (2018), available at: \{https://www.atlanticcouncil.org/in-depth-research-reports/report/toward-long-term-solidarity-with-syrian-refugees-turkey-s-policy-responseand-challenges/\} accessed 24 January 2021.

${ }^{100}$ Fulya Memişoglu and Asli Ilgit, 'Syrian refugees in Turkey: Multifaceted challenges, diverse players and ambiguous policies', Mediterranean Politics, 22:3 (2017), pp. 317-38; Polat, 'Religious solidarity, historical mission and moral superiority’; Yanaşmayan, Üstübici, and Kaşlı, 'Under the shadow of civilizationist populist discourses', p. 47.

${ }^{101}$ Polat, 'Religious solidarity, historical mission and moral superiority', p. 510. Note: The language of humanitarian, emotional and hospitality are also language used in liberal thought (Kant comes to mind), but the difference here is the cultural attachment: Turkish people are supposed to show these qualities not so much as human beings, but more so as Turkish (or Muslim) people - and as highlighted below, there is a certain ambiguity as to whether all human beings can be the recipient of this generosity or whether only 'kins' (other sunni Muslims) are concerned. See Balkılıç and Teke Lloyd, 'Does Islamic inclusion of Syrians represent'.
} 
in a state of permanent dependency towards their 'generous' host, and leaves them in a precarious limbo. ${ }^{102}$

This particular discourse is interesting for two main reasons. The first one is that it is a different, somewhat contradictory discourse to the decentring (with a new centre) one discussed above. Here Turkey is no longer faring well on European standards, but rather European standards are deemed inferior or unworthy. This is somewhat a critique of Eurocentrism as it refuses to accept Eurocentric normative definitions. The ideal future is no longer one defined by Europe. But by doing so, it falls into an orientalist (or occidentalist) frame of understanding, that affirms and reinforce an ontological and essential difference between Europe and Turkey. The West/East dichotomy is kept untouched, only the normative evaluation of these two categories is changed, in fact inverted. ${ }^{103}$ Ayhan Kaya, Max-Valentin Robert, and Ayşe Tecmen had indeed already discussed the persistence of the 'Huntingtonian dichotomous worldview' ${ }^{104}$ in the Turkish rewriting of multiculturalism.

The second reason is indeed that the hierarchical understanding of values is not fundamentally changed, but rather inverted. The Turkish approach (sometimes phrased as a 'Muslim' approach) towards migrants is almost systematically contrasted to the cold and inhuman European/Western approach. ${ }^{105}$ Accordingly, Turkish actors live under the imaginary gaze of the West, and intently rebel against it, by inverting the hierarchy of values. For instance, Ahmet Davutoglu talks about what distinguishes the Turkish approach to Syrian refugees from the 'European' or 'Western' one as being one of 'humanitarian diplomacy' that is 'all-encompassing'. The full quote reads:

However, in the case of a humanitarian tragedy, Ankara feels obliged to extend its assistance even outside its borders, in line with its conscience-oriented understanding of diplomacy. Over 180,000 Syrian people are hosted in Turkey, due to the humanitarian tragedy in their home country. This all-encompassing approach is the most significant and distinguishing aspect of Turkey's humanitarian diplomacy. ${ }^{106}$

If, in the West, a rights-based approach is deemed more important than a humanitarian approach, then the Turkish 'better' way is to invert this hierarchy where culturally situated generosity prime over rights. It seems likely, however, that this new hierarchy is not created autonomously in a vacuum, but rather is constructed against the standard of the 'European hierarchy'. The referent remains Europe, the binaries remain the same, only the order in inversed. Accordingly, Eurocentrism is being preserved here, albeit in a modified manner.

Of additional concern is the fact that this reversed hierarchy of norms, premised on an ontological dichotomy, does not allow room to eschew the shortcomings of Eurocentrism. At the core of the Turkish critique of the European approach towards migration was the tendency to securitise immigrants, as well as the enactment of exclusive practices towards migrants. Balkılıç and Teke Lloyd, in their analysis of the inclusion of Syrians have demonstrated how both securitisation and exclusive practices are reproduced (in a modified manner) under a

\footnotetext{
${ }^{102}$ Şenses, Nazl. 'Rethinking migration in the context of precarity: The case of Turkey', Critical Sociology, 42:7-8 (2016), pp. 975-87; Baban, Ilcan, and Kim Rygiel, 'Syrian refugees in Turkey'; Fırat Genç, Gerda Heck, Sabine Hess, 'The multilayered migration regime in Turkey: Contested regionalization, deceleration and legal precarization', Journal of Borderlands Studies, 34:4 (2019), pp. 489-508.

${ }^{103}$ See Balkılıç and Teke Lloyd, 'Does Islamic inclusion of Syrians represent', p. 12: 'Through these narratives and scripts, the Turkish discourse effectively inverted the West/East dichotomy, asserting the supremacy of Islamic norms and values over those of Europe.'

${ }^{104}$ Ayhan Kaya, Max-Valentin Robert, Ayşe Tecmen, 'Populism in Turkey and France: Nativism, multiculturalism and Euroskepticism', Turkish Studies, 21:3 (2020), pp. 361-91 (p. 385).

${ }^{105}$ Polat, 'Religious solidarity, historical mission and moral superiority'.

${ }^{106}$ Ahmet Davutoğlu, 'Turkey’s humanitarian diplomacy', p. 867.
} 
inverted hierarchy worldview, with the creation of binary categories of 'deserving Muslims' vs 'Others'. 107

\section{Conclusion}

This article aimed to provide some conceptual clarification regarding the politics of anti-Eurocentrism and to better understand the mechanisms through which Eurocentrism gets inadvertently reproduced. The conceptual framework developed here highlights different types of anti-Eurocentrism, including rhetorical critique, deconstruction, decentring, and dehierarchising. Within both decentring and dehierarchising approaches, there are different types of alternatives: some of them help transcend Eurocentrism and reach post-Eurocentrism, while others (in particular new centre and inverted hierarchy) lead to a form of reproduction of Eurocentrism.

To illustrate how some of these work in practice, we looked at the evolution of Turkish policies towards immigration and asylum, which has been used as an area where the Turkish leadership has attempted to challenge Eurocentrism. Yet, most of this political activism has inadvertently led to a reproduction of Eurocentrism, rather than overcoming it. At times, as was manifested in the adoption of the readmission agreement and the EU-Turkey deal, it was because the principles used demonstrated a superficial understanding of Eurocentrism or a weak commitment to anti-Eurocentrism. At other times, as when Turkey engaged in critical Europeanisation, it was because Turkish authorities adopted the Eurocentric framework, and simply replaced Europe with Turkey at the centre (new centre approach). Another instance demonstrated elements of an inverted hierarchy process, where the prioritisation of cultural generosity over rights is seen as the righteous opposite to the European hierarchy, which remains the frame of reference. In all of these cases, Eurocentrism is reproduced rather than being overcome.

By doing so, this analysis also provides a novel contribution to the empirical analysis of Turkish foreign and migration policies, in particular their discursive dimension. It highlights a core contradiction in the Turkish official discourse on migration (that is likely also present in the broader frame of foreign policy): it tries to affirm ontological sameness with Europe in order to affirm Turkey's equal (if not superior) moral status (based on European standards); and at the same time, it asserts ontological difference with Europe, to declare itself as a better alternative. ${ }^{108}$ European norms are adopted and rejected at the same time.

At the theoretical level, this analysis raises an interesting question regarding the value of the modified reproduction of Eurocentrism. One way to evaluate this 'failed' attempt at overcoming Eurocentrism is to highlight the fact that the more one tries and fails to challenge a structure, the more this structure becomes legitimised and strengthened as the only possible structure, with no viable or better alternative. It may reify this structure more than it uncovers it $^{109}$ and Eurocentrism gains validity perniciously. However, another way to think about it is to recognise that even if the attempt at challenging ends up reproducing Eurocentrism, it does so in a modified manner, and this pokes holes at the hegemonic implementation of Eurocentrism.

And to further understand the value of modified reproduction, there is a need again to differentiate between geopolitical and epistemic modified reproduction of Eurocentrism. From a purely geopolitical standpoint (and as seen by practitioners of world politics), the criteria for success when engaging in anti-Eurocentrism might be different from the one of epistemic Eurocentrism. On the one hand, for geopolitical Eurocentrism, the consequences of reproduction are immediate and real, as here the concerning - modified but continuous - practice of exclusive, volatile, and arbitrary policies towards migrants. ${ }^{110}$ But on the other hand, there might be

\footnotetext{
${ }^{107}$ Balkılıç and Teke Lloyd, 'Does Islamic inclusion of Syrians represent', p. 14.

${ }^{108}$ See also Çınar, 'Turkey’s "Western” or "Muslim” identity'.

${ }^{109}$ See also Anderl and Witt, 'Problematising the global in global IR'.

${ }^{110}$ Balkılıç and Teke Lloyd, 'Does Islamic inclusion of Syrians represent', p. 3.
} 
strategic considerations that justify modified reproduction as a temporary step towards a more post-Eurocentric future. ${ }^{111}$ Such strategic considerations cannot be claimed in the case of epistemic Eurocentrism. Accordingly, the efficiency of modified reproduction by practitioners can be seen as a glass half-full. But the dangers of prioritising political goals over principled actions can also lead to self-defeat, as the discussion of pragmatism above highlighted. Pragmatism can too easily become a tool in the service of the reproduction of Eurocentrism, a concern uniquely relevant to practitioners. In addition, practitioners might be more interested in the process of overcoming Eurocentrism, rather than in the actual realisation of post-Eurocentrism. As seen in speeches quoted above, what is of interest to the Turkish ruling elite is to be seen as the champion that overturned Eurocentrism. ${ }^{12}$ Political benefits of popularity can be reaped during the process of overcoming, not so much during the 'aftermath'.

This finally calls into question the thorny issue of what post-Eurocentrism would really look like. ${ }^{113}$ The strategies of building a world with no centre and no hierarchy, seem as elusive epistemologically as it is politically. What seems clear is that this will require analyses and praxis that include the agency and responsibility of a wide range of actors, including actors positioned similarly to Turkey's current ruling elite, but also actors situated closer to the Eurocentric core, and actors that are furthest away from centres of power (such as migrants and refugees in this analysis).

Acknowledgements. The author would like to thank three anonymous reviewers for the Review of International Studies for their meaningful and constructive comments.

Juliette Tolay is Associate Professor of Political Science in the School of Public Affairs at Penn State Harrisburg. Her work on migration, Turkey and foreign policy have appeared inter alia in International Migration, Journal of Refugee Studies, Ethnopolitics, Les Etudes du CERI, and several edited volumes. She is co-author of Turkey and Its Neighbors: Foreign Relation in Transition (2012). Dr Tolay is a former fellow at the Transatlantic Academy of the German Marshall Fund.

\footnotetext{
${ }^{111}$ Christophe Murray points at this in his analysis of Du Bois and Fanon texts: 'In the process of political/activist praxis, representation might take different forms depending on the strategic content of the dialectical response to hegemony. Essentialism might be condoned in these circumstances, or simply emerge as a reaction. However, it is not the role of academic praxis to condone essentialism, but to offer accounts for why or how it is possible for essentialism to take place. Yet, it is essentialism in academic praxis, which is sometimes produced by anti-Eurocentric IR.' Christopher Murray, 'Imperial dialectics and epistemic mapping: From decolonization to anti-Eurocentric IR', European Journal of International Relations, 26:2 (2020), pp. 419-42 (p. 428).

${ }^{112}$ Aydın-Düzgit, 'De-Europeanisation through discourse', p. 51.

${ }^{113}$ See fn. 30 .
}

Cite this article: Tolay, J. 2021. Inadvertent reproduction of Eurocentrism in IR: The politics of critiquing Eurocentrism. Review of International Studies 47, 692-713. https://doi.org/10.1017/S0260210521000176 